\title{
Developing Animated Video for Patisserie Learning
}

\author{
Yulia Rahmawati*, Sudewi Yogha, Asep Maosul \\ Study Program of Education Culinary Art \\ Faculty of Technology and Vocational Education \\ Universitas Pendidikan Indonesia \\ *yuliarahmawati@upi.edu
}

\begin{abstract}
This study aims to design video animation for patisserie learning in vocational education, especially the learning patisserie which requires students to have skills in practicing pastry and bakery. It requires a companion learning facility when it take place in the outside of the classroom by using effectively and efficiently learning methods such as presenting pastry and bakery with clearly explanation and steps which is does not need to use internet access or training courses to learn them. This "Pastry and Bakery " animated video is created using the rigging bone and cell shading method with 2 Dimensional model, with the mp4 extension, it is used $1280 \times 720$ video resolution, and a frame rate of $24 \mathrm{fps}$. In making the animation, it is used Powtoon. PowToon can be a solution for students who are not present at the practicum because it can provide an overview by viewing animated video shows, besides that students can repeat the material and download it on the provided link anytime and anywhere.
\end{abstract}

Keywords—animated video, patisserie learning

\section{INTRODUCTION}

The growth of technology is getting faster currently based on the growth of mathematics in various fields. Mathematics is a field of study that supports the growth of science and technology [1]. Media is a source of learning so that learning media can be broadly interpreted by humans, objects and events that allow students to acquire knowledge and skills. Media is a tool that can be anything to be used as a channel for messages to achieve learning objectives [2]. With the existence of instructional media is one component in the learning process that is required, given that the existence of media is not just a teaching support, but it is also an integral part of the learning process [3].

Learning media as an implementation of the educators task in presenting material, it is also has unique potentials that can help students in learning. So, it is necessary to develop good and creative learning media so that it can increase the attractiveness of students to learn about history. Several alternative learning media that can be used in history learning, one of which is the animated video media.

Video is a very effective media to assist the learning process. Videos are rich in information and quite complete because they come directly to the students [4]. Video adds a new dimension to the history learning. It is because videos are able to present moving images and sound to the students. The ability of video in visualizing material is very effective in helping educators deliver dynamic material. The packaging of video media is combined with animation.

Animation is an activity to animate, moving still objects. An inanimate object is given a boost of strength, enthusiasm and emotions to become alive and moving or just seems alive [5]. Animation is a still object that is projected into a moving image that seems to live in accordance with the characters made from several sets of images that change regularly and take turns according to the design, so that the video displayed is more varied with attractive and colorful images that can increase the learners attractiveness.

Learning media need to be developed by utilizing technology that is supported by the availability of facilities in schools. One of the advantages of using video is that it can enrich the presentation or explanation effectively and efficiently [6]. Teachers or lecturers can use several applications that can be presented in video form, including videoscribe, PowToon, animaker, and so on. Villar argues that PowToon is a web-based application provided for users to create animated videos by manipulating objects, importing images, providing music and users can add various sound [7].

Learning videos which made with PowToon are suitable for use and can improve students' understanding of mathematical concepts. The differences between this study and previous studies were 1) the duration of the video was longer, which was approximately 13 minutes; 2) various animations are used to serve as an illustration relating to everyday life; and 3) using sound recordings as support to clarify the material presented [8].

The patisserie course with the competence to make cake and bakery products is one of the competency that students must mastered, but in laboratory implementation, there are students who have not mastered these competency. In the implementation of practicum lectures, students often encounter obstacles or having difficulties in carrying out practicum in the laboratory. Beside, they often make mistakes in making patisserie products, even though it was previously explained during the theory and they had been given a recipe and a job sheet as a guide in carrying out practicum. The solution to these problems, the researcher designed a learning media that could improve students' understanding and skills in practicum implementation. Based on these problems, the researchers conducted a study entitled "Developing Animated Videos for Patisserie Learning" 


\section{RESEARCH METHODS}

This study aims to produce instructional media in the form of animated videos in learning pastry subjects. In the process of making animated videos with pow-toon the method of making was developed by Villamil-Molina which consists of four stages, namely development, preproduction, production, postproduction [9].

At the development stage, adjusting the concept of multimedia products, begins to be compiled and formed based on existing ideas. At this stage, the authors conducted 3 techniques in collecting data for making pow-toon animation videos, namely by carrying out literature studies, observations, interviews. In this second stage, preparations for working on multimedia products. This stage is an important stage in making pow-toon animated videos. The design includes making storylines, story scripts, and storyboards, making character designs and background used in each scene.

Furthermore, dubbing is carried out for each character in the story. In this stage, the output of the animated video is also determined, including format, resolution, framerate, and duration. In this third stage, the animation production process begins, the animation process of the characters (modeling) and the background that was previously made is carried out. At this stage also the dubbing process that has been done previously is inserted in the animation process using Pow-toon software. In this fourth stage, multimedia products that have been made will enter the testing phase.

\section{RESULTS AND DISCUSSION}

Types of learning media are divided into seven classifications, namely: (1) motion audio visual media, (2) silent audio visual media, (3) semi-motion audio, (4) motion visual media, (5) silent visual media, (6) audio media and (7) print media [10].

Pastry is one of the courses in the Culinary Education Study Program at the Indonesia University of Education which discusses making cakes and pastries, and also have ability in making cakes and pastries for various occasions. This subject is more than about the implementation of learning and carries out many practical activities. Therefore, the researcher developed a learning media in animated video for pastry courses and will be practiced by students.

The animation PowToon is chosen as the video media in this learning research because PowToon provides more animation than other applications. The animation can also be easily adjusted according to the user's preferences so that it is easy to provide an illustration related to the material to be presented. PowToon animation is an application that has powerful features in one screen, which can create various animations as needed. In this learning, it was also stated that animation has many advantages, such as being able to eliminate boredom in learning, arousing learning passion, and of course animation can attract students' attention to stay focus in the learning process [11].

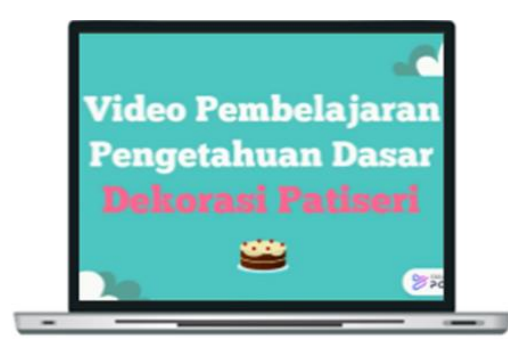

Fig. 1. First page of PowToon Animation.

Figure 1 shows the first page of the PowToon animation video, which contains the title and course. The researcher took one of the patisserie decoration courses with the competence of making cake decorations. The initial appearance in the application must be made uniquely, this animated video "Pastry Decoration" was created using the bone rigging method and cell shading with a 2-dimensional model, which lasted 03 minutes 47 seconds, with mp4 extension specifications, video resolution $1280 \times 720$, and frame rate of $24 \mathrm{fps}$ so that the presentation or video that we make is easy to change colors, photos, and text.

This competency is one of the competencies that must be mastered by students, before carrying out the practice, students are usually given a job sheet, but students still do not understand the stages in carrying out the practicum. Therefore, researchers develop animation management students can better understand and be able to achieve competence in carrying out practicum. PowToon is a web-based animation software that allows you to quickly and easily create animated presentations with your students by manipulating pre-created, imported objects. images, provided music and user created voice-overs [12].

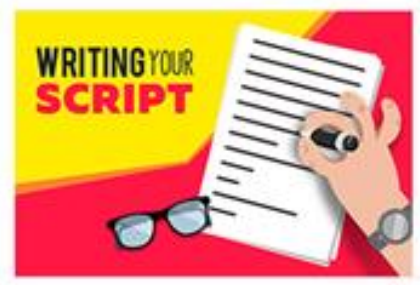

Fig. 2. Writing script.

Figure 2 show a page of writing script, The script is the foundation in a video, so it can be understood that the script has a function as a basic concept.

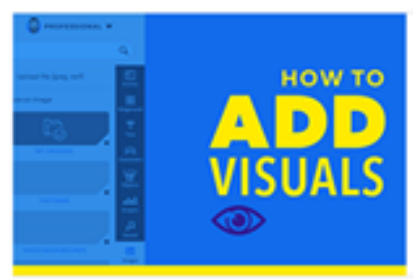

Fig. 3. Add visuals.

Figure 3 shows a page add visuals, make a video starts from recording a video with scripts and concepts that have been 
designed from scratch. Then the recording process, both visual and audio, is carried out, and all elements work together in the production process. In the production process we must prepare: computer (personal computer) or laptop, an image capture tool (camera), cellphone or webcam and video screen.

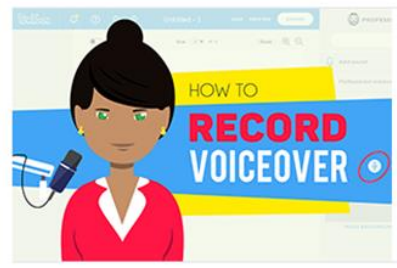

Fig. 4. Record video.

Figure 4 shows a page of record voiceover, the sound function includes a number of purposes, such as making illustration music, making sound effects, and sound recording (for narrative dubbing purposes). Of the stages in making the PowToon animated video. Before accessing Powtoon, you have to create an account first. To do this, click 'sign up' or 'login'. Write scripts or jobsheets, fill in voice and add animated audio visuals that will be added to the video.

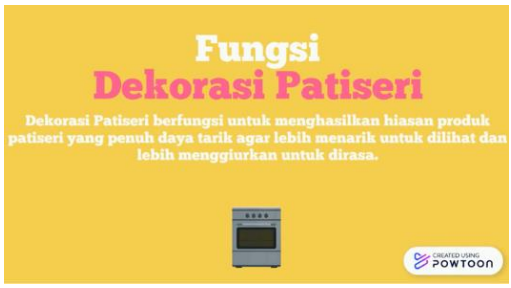

Fig. 5. Video slideshow.

Figure 5 shows one of the slide shows in the PowToon animated video. The selection and use of video and animation media for learning is customized to the needs, effectiveness and efficiency based on the advantages and disadvantages of each of these learning media. Pastry animation videos that are used as learning media must be able to motivate students to learn so they are not bored, one of which is the application of learning media that is in accordance with the material so that the learning outcomes obtained can be maximized. Some learning media that can be used are video and animation media. The media must be tested in order to find the best media to provide maximum learning outcomes in all aspects (cognitive, psychomotor and affective).

The PowToon animation video as a media that has been created can help students understand the learning material well and can be conducted in campus. The PowToon animation video can be repeated if students do not understand the learning material, so that when the practicum is carried out, students have mastered competency and minimized failures in practicum implementation. The practicality of the media is related to the compensatory function of the media. Media can be said to have a compensatory function if the media can help students who are weak or slow to accept and understand the content of the lessons presented [13]. This is in accordance with the advantages of animated video-based learning media which can play back learning material if students do not understand. In addition, the use of media is more practical, it can be used repeatedly anywhere and anytime so that students can use it as needed.

The development of PowToon animation learning media is packaged which contain an illustration related to the patisserie material (cake decoration, etc.). The content is customized to the learning objectives to be achieved from the learning process using this animation media in the form of animated videos. Learning using video is carried out so that the delivery of material can be more interesting and clear [14].

\section{CONCLUSION}

Interactive multimedia-based learning media in the form of animated videos is expected to make students do not get bored and enthusiastic in paying attention to the pastry lecture practicum learning. By using animation video learning media, PowToon can be a solution for students who are not present at the practicum because it can provide an overview by viewing animated video shows, besides that students can repeat the material and download it on the provided link anytime and anywhere. Interactive multimedia-based learning media in the form of animated videos can be a solution in presenting learning so that it is not getting monotonous.

In the implementation of practicum requires students to have knowledge and skills, therefore this animated PowToon petisserie video can be a stimulus in the implementation of the learning process, especially the implementation of practicum. Petisserie learning using video-animation media can improve student skills and competency, so it is expected that lecturers can combine this media with an interesting learning model and according to student characteristics. Beside, the next researcher can carry out further research for other materials using animation learning video media in other lessons.

\section{REFERENCES}

[1] M.l. Niess, "Preparing teachers to teach science and mathematics with technology: Developing a technology pedagogical content knowledge". Teaching and teacher education, 21(5), 509-523. 2005.

[2] C. Greenhow and B. Robelia, "Informal learning and identity formation in online social networks. Learning”, media and technology, 34(2), 119 140. 2009.

[3] I.A. Ainina, "Pemanfaatan Media Audio Visual sebagai SumberPembelajaran Sejarah". Indonesia Journal Of History Education, Vol.3(1). 2014.

[4] W.S. Harwood and M.M. McMahon, "Effects of integrated video media on student achievement and attitudes in high school chemistry". Journal of Research in Science Teaching: The Official Journal of the National Association for Research in Science Teaching, 34(6), 617-631. 1997.

[5] P. Manning, Animating virtual worlds: Emergence and ecological animation of Ryzom's living world of Atys. First Monday. 2018.

[6] Munir, Multimedia Konsep dan Aplikasi dalam Pendidikan. Bandung: CV Alfabeta. 2015

[7] L. Kilgus, C. Force, and I.M. Powell, "Developing a Comprehensive Matrix: An Instructor's Resource for Using Free Web-Based Applications for Business Communication Courses". Journal of Applied Research for Business Instruction, 14(1), 1. 2016.

[8] S.M. Asyifa, Pengembangan Video Pembelajaran untuk Mengembangkan Kemampuan Pemahaman Konsep Matematis Siswa Sekolah Dasar. 
(Doctoral Dissertation). Serang: Universitas Sultan Ageng Tirtayasa. 2018

[9] J. Villamil-Casanova and L. Molina, Multimedia: An introduction. Indianapolis, IN: QUE E\&T. 1997.

[10] Z. Arifin and A. Setiyawan, Pengembangan Pembelajaran Aktif dengan ICT. Yogyakarta: Skripta Media Kreatif. 2012.

[11] B.S.P. Teoh and T.K. Neo, "Interactive Multimedia Learning: Students' Attitudes and Learning Impact in an Animation Course". Online Submission, 6(4). 2007.
[12] S. Mershand, 2014.

[13] Z. Morsy, Preface. In Z. Morsy (Ed.) Media education pp 5-12 (Paris: UNESCO). 1984.

[14] M. Rioseco, F. Paukner-Nogués, and B. Ramírez-Muñoz, Incorporating Powtoon as a learning activity into a course on technological innovations as didactic resources for pedagogy programs. 2017. 